\title{
Giv ansvaret til afghanerne
}

\section{Jens Ringsmose E $\mathcal{O}$ Peter Dahl Thruelsen}

\section{En vestlig exit-strategi må basere sig på dannelsen af en slagkraftig afghansk hær og en duelig afghansk politistyrke. Jo før afghansk militær og politi kan overtage de funktioner ISAF-styrkerne udfører i dag, jo før kan den vestlige militære tilstedeværelse reduceres}

Siden begyndelsen af 2006 har Taleban, Hezb-e Islami, al-Qaeda og andre af de mange væbnede grupperinger, der huserer i Afghanistan, optrappet deres voldelige aktiviteter rettet mod Karzai-regeringen og dens internationale støtter.

Oprørsgrupperne - og i særdeleshed Taleban - blev ganske vist tilført betydelige tab i $2006 \mathrm{og}$ begyndelsen af 2007, men det har ikke hindret magtudfordrerne i at øge antallet af angreb rettet mod NATOs ISAF-styrker, de afghanske sikkerhedsstyrker samt civile afghanere.

For NATO og Vesten har det seneste halvandet års betydelige vækst $\mathrm{i}$ oprørernes voldelige udfoldelser været med til at tydeliggøre behovet for opbygningen af en effektiv afghansk sikkerhedssektor med kapacitet til at løfte de opgaver, de inter- nationale ISAF-styrker varetager i øjeblikket. Det vestlige engagement i Afghanistan kan ikke erklæres for en langsigtet strategisk succes - og dermed tilendebragt - før, der er etableret et stabilt demokratisk og $\varnothing$ konomisk bæredygtigt styre, der vel at mærke er i stand til at tage vare på egen sikkerhed.

Alt peger dermed i retning af, at en realistisk vestlig exit-strategi uværgeligt må basere sig på blandt andet dannelsen af en slagkraftig afghansk hær og en duelig afghansk politistyrke. Jo før det nye afghanske militær og politi er i stand til at overtage de funktioner ISAF-styrkerne udfører i dag, jo før kan den vestlige militære tilstedeværelse i Afghanistan reduceres.

Etableringen og indsættelsen af afghanske styrker i bestræbelserne 
på at stabilisere specielt de sydlige og østlige dele af landet vil endvidere kunne bidrage til en 'afghanisering' af kampen mod de primært talebanske oprørsstyrker. Sideløbende med at den afghanske hær opbygges, kan de vestlige styrker træde tilbage og overlade opgaven til afghanerne selv.

En sådan udvikling vil med stor sandsynlighed medvirke til, at den lokale befolkning i stigende grad kommer til at betragte kampen mod oprørerne som mere legitim. Konflikten vil ikke længere stå mellem på den ene side udefrakommende magter, som oprørerne har let ved at fremstille som et fremmedelement og på den anden side talebanere af afghansk oprindelse, men mellem repræsentanter for den afghanske stat og regeringsfjendtlige oprørsstyrker.

Men hvor står de afghanske sikkerhedsstyrker rent faktisk? Hvor langt er USA og ISAF nået i bestræbelserne på at opbygge en effektiv afghansk sikkerhedssektor? Er der udsigt til at rygraden i en fremtidig 'afghaniserings-strategi' - Afghan National Army (ANA) og Afghan National Police (ANP) - vil være i stand til at løfte opgaven?

Formålet med denne artikel er først og fremmest at give en vurdering af ANA's øjeblikkelige tilstand. Med afsæt i et feltarbejde gennemført i Afghanistan i april 2007 konkluderer vi, at den afghanske sikkerhedssektor endnu er langt fra at kunne træde i stedet for de internationale styrker, men den positive udvikling i den afghanske hær giver grobund for en forsigtig optimisme. Under forudsætning af at det internationale samfund ikke reducerer støtten til opbygningen af landets væbnede enheder i de kommende år, er det sandsynligt, at konflikten langsomt vil 'afghaniseres'. For at sætte oprørskrigen i Afghanistan i relief - og samtidig understrege nødvendigheden af at Vesten ikke negligerer betydningen af et større afghansk bidrag i oprørsbekæmpelsen - vil de følgende sider imidlertid blive indledt med kortfattet kategorisering af den verserende konflikt.

\section{Hvorfor afghanisering?}

I kølvandet på de amerikansk-ledede interventioner og efterfølgende statsbygningsprojekter i Afghanistan og Irak er vestlige militære styrker i et stadig stigende omfang blevet involveret i en særegen konflikttype: oprørskrigen.

Vestens - og især USA's - fuldstændige overlegenhed på det konventionelt militære område resulterede i løbet af ganske kort tid i Taleban- og Baath-regimernes totale kollaps, men bestræbelserne på at erstatte de diktatoriske styreformer med demokratier efter vestligt forbillede har i stor udstrækning lidt under forskellige oprørsgruppers forsøg på at destabilisere og afspore opbygningsprocessen. For Vestens 
militære styrker har konsekvensen været et presserende behov for at lægge koldkrigsperiodens doktriner bag sig for at genopfinde sig selv som oprørsbekæmpere.

At de vestlige styrker i Afghanistan har haft så vanskeligt ved at neutralisere oprørerne hænger imidlertid også sammen med, at konflikten tilhører en overordnet type af oprør, der kun sjældent har efterladt oprørene som tabere. Set lidt fra oven er det således muligt at sondre mellem to typer af oprørsaktiviteter: Nationale oprør og uafhængighedsoprør. I et historisk perspektiv har det altid været vanskeligst at pacificere sidstnævnte oprørskategori - og det er netop denne type oprørskrig Vesten er en del af i Afghanistan.

Det nationale oprør kan have rødder i blandt andet religiøse, etniske eller sociale forhold, men afgørende er det, at krigens primære parter er de nationale myndigheder og oprørsbevægelsen. Såvel oprørere som de nationale magthavere kan være støttet af udenlandske mæcener, men konfliktens hovedskillelinje løber mellem den indenrigspolitiske gruppering, der på den ene side kontrollerer hovedstaden og statsapparatet og den gruppe, der på den anden side tager sigte mod at gennemføre et regimeskifte med voldelige midler. Konflikterne i Peru, Guatemala og Kina (1945-1949) er eksempler på nationale oprørskrige.

Heroverfor står uafhangighedsoprøret. I denne type af oprørskrig står hovedkonflikten mellem oprørerne og en herskende gruppe, der af oprørerne og lokalbefolkningen opfattes og fremstilles som en udefrakommende besættelsesmagt, der på væsentlige punkter - eksempelvis etnisk, religiøst og kulturelt - adskiller sig fra befolkningsflertallet. I kampen for at overvinde fjenden søger oprørsbevægelsen at fremstille sig selv som en befrielsesorganisation, der med alle til rådighed stående midler søger at uddrive fremmedlegemet. Vietnam-krigen, den tjetjenske opstand og de nuværende oprør i Irak og Afghanistan er alle eksempler på oprørskrige, der placerer sig i kategorien uafhængighedsoprør.

\section{Betydningen af fælles identitet}

Den væsentligste årsag til, at uafhængighedsoprør oftest er yderst vanskelige at overvinde, skal søges i det forhold, at oprørskonflikter kun sjældent vindes uden den brede befolknings opbakning. Vejen til sejr går næsten uomgængeligt over lokalbefolkningens hearts and minds.

Såvel oprørerne som den regering, oprøret er rettet imod, er derfor afhængige af lokalbefolkningens gunst. Fordi oprørerne i reglen deler nationalitet, religion og etnicitet med store dele af indbyggerne i det oprørsramte land, er det relativ problemfrit for magtudfordrerne at fremstille magthaverne som en udefrakommende kræftsvulst, der - om nødvendigt - skal fordrives med 
magt. Identitetsfællesskabet med lokalbefolkningen bliver dermed et af oprørernes vigtigste aktiver.

Set i det lys er der al mulig grund til at forcere nationaliseringen/afghaniseringen af konflikten i Afghanistan. Jo hurtigere ANA og ANP bliver i stand til at overtage dele af ISAF-styrkernes opgaver, jo større er også sandsynligheden for, at afghanerne i højere grad vil opfatte og fortolke konflikten som et nationalt anliggende. Selv om de afghanske styrker ikke har samme færdigheder som deres vestlige mentorer, kan der således være god ræson $\mathrm{i}$ at give dem større ansvar. For, som T. E. Lawrence - alias Lawrence of Arabia - bemærkede, da han klargjorde arabiske styrker til kamp under Første Verdenskrig: "It is better to let them do it themselves imperfectly than to do it yourself perfectly. It is their country, their way, and our time is short".

\section{Opbygning og organisering af ANA}

Opbygningen og uddannelsen af ANA blev påbegyndt $i$ begyndelsen af 2002 og kan - sammenlignet med lignende projekter gennemført i blandt andet Afrika og Irak - generelt betegnes som en succes.

Målet med opbygningen af ANA er at have en styrke på ca. 70.000 mand bestående af både kampsoldater, støtteelementer, luftvåben (opbygningen af det afghanske luftvåben - Afghan National Army Air
Corp (ANAAC) - er netop blevet påbegyndt. Målet er at uddanne ca. 3.000 mand, der skal kunne betjene både transportfly, helikoptere og jagerfly. Opbygningen og uddannelsen ledes af USA) og stabe klar med udgangen af 2010. I skrivende stund er der indrulleret ca. 35.000 soldater, hvoraf størstedelen allerede er stationeret i de afghanske provinser.

Etableringen af ANA har til dato været centralt styret af amerikanerne, der har haft hovedansvaret for alle ANA-soldaters grunduddannelse i Kabul. Den amerikanske enhed, der varetager uddannelsesopgaven, består af ca. 2.000 instruktører og administrativt personel, der planlægger og støtter gennemførelsen af grunduddannelsen. For at sikre et nationalt ejerskab og en bæredygtig udvikling af opbygningen af ANA er der derudover tilknyttet et større antal afghanske officerer og instruktører, som står for den daglige ledelse og uddannelse ved uddannelsescentret i Kabul.

Overordnet er ANA struktureret med et forsvarsministerium i Kabul, der under sig har fem regionale korps. De fem korps har hver især afhængigt af sikkerhedssituationen i de enkelte regioner - et antal brigader (på ca. 3.000 mand) underlagt. Det centrale korps - 201. Korps der er placeret i Kabul, har desuden en Quick Reaction Force tilknyttet, der, når den er fuldt etableret, vil være i stand til at forstærke de regionale korps i krisesituationer. 


\section{De fem korps}

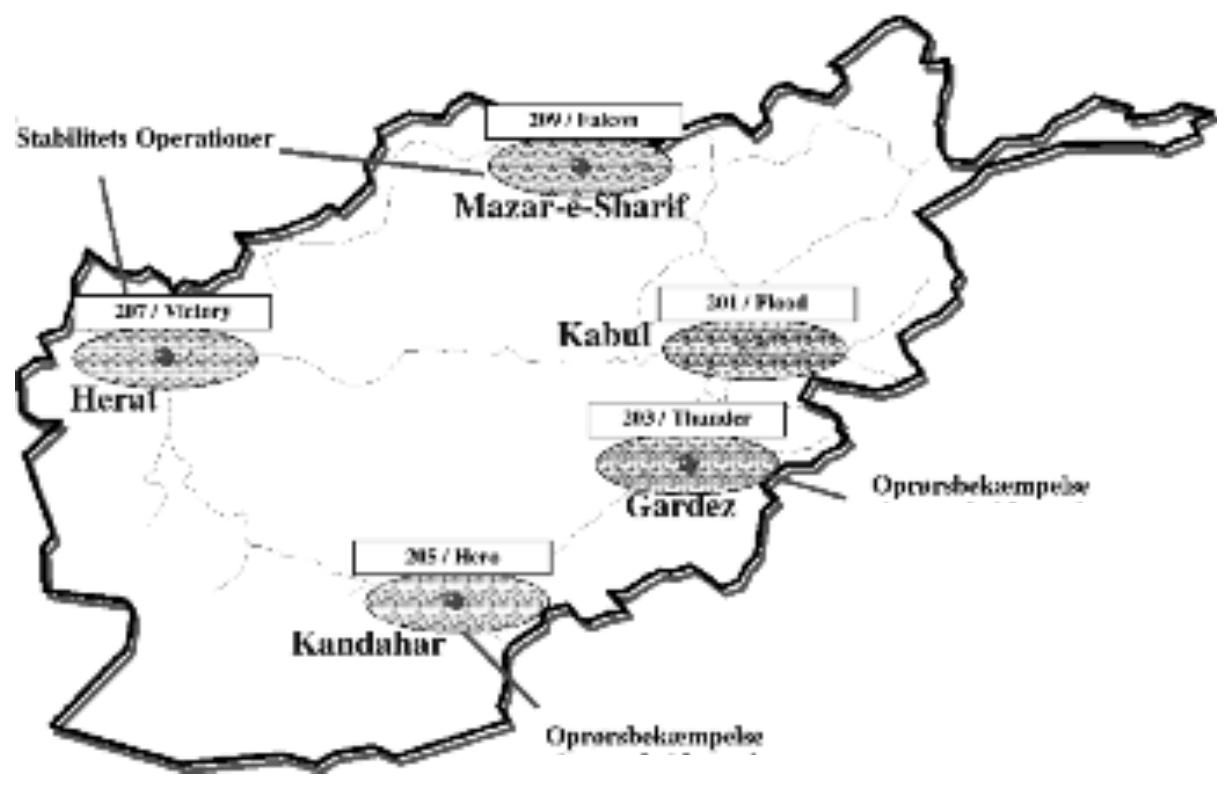

Kort 1: Oversigt over placeringen af de fem ANA korps.

De to korps i henholdsvis $\emptyset$ st- og Sydafghanistan gennemfører primært regulære kampopgaver i form af oprørsbekæmpelse kraftigt støttet af de internationale styrker, mens de to korps i Nord- og Vestafghanistan hovedsageligt er optaget af stabilitetsorienterede opgaver i form af patruljeringer og bemanding af kontrolposter.

Når den enkelte soldat tegner kontrakt med ANA, er det som regel for en treårig periode. Alle nyrekrutterede soldater starter med at gennemgå grunduddannelsen i Kabul. Efter endt grunduddannelse sendes soldaterne ud til de fem regionale korps for at indgå i de allerede etablerede brigader og bataljoner (afghansk: kandak - ca. 700 mand). Ved ankomst til korpsene tilstræbes det, at soldaterne gennemfører yderligere træning med de enheder, de skal indgå i. Det er dog ikke altid muligt at gennemføre den supplerende træning på grund af mangel på instruktører, og fordi de omfattende kamphandlinger i specielt de østlige og sydlige egne gør soldaterne efterspurgte i felten.

Indtil nu har ANA ikke været plaget af rekrutteringsproblemer. I de 
første fire måneder af 2007 er målet på 2.000 nye hvervede rekrutter om måneden fuldt ud nået. Fastholdelsen af de nye rekrutter er derimod et stort problem, som den centrale ledelse af ANA har haft vanskeligt ved at håndtere. Fastholdelsesproblemerne skyldes flere omstændigheder, men dårlige fritids-, besøgsog beboelsesfaciliteter ved de fem korps og det meget krævende operationsmiljø i Syd- og Østafghanistan er utvivlsomt en væsentlig del af forklaringen.

Det er blandt andet et udtalt problem for de professionelle soldater, officerer og instruktører, at de ikke har mulighed for at bo alene eller sammen med deres familier, hvorfor de ofte - uden tilladelse - forlader lejren i længere perioder for at aflægge hjemegnen besøg. Dette har selvsagt en negativ effekt på de menige, der også hyppigt uden tilladelse tager hjem under tjenesten for at besøge familien. Også operationsvilkårene i de sydlige og østlige dele af landet har haft en negativ effekt på fastholdelsen.

Når de menige soldater har afsluttet grunduddannelsen i Kabul og derefter skal sendes ud til et af de fem korpshovedkvarterer, sker der ofte en stor afvandring blandt de menige, der skal overføres til korpsene i øst eller syd. Ved disse to korps er overlevelsesmulighederne på grund af de mange kampoperationer væsentligt dårligere og nedslidningsraten betydeligt højere, hvilket gør, at mange nyuddannede soldater deserterer.

I et forsøg på at imødegå det stigende fravær har man fra det afghanske forsvarsministerium side indført en cyklus for træning, operationer og orlov ved de fem korps. En cyklus består af fire ugers træning efterfulgt af seks uger med operationer. Cyklusen afsluttes med

Tabel 1

Antal fraverende soldater $i$ forhold til den faktiske tildeling fordelt på de fem korps

\begin{tabular}{|cccccc|}
\hline Korps & Autoriseret & Tildelt & $\begin{array}{c}\text { Autoriseret/ } \\
\text { Tildelt }\end{array}$ & Fravær & $\begin{array}{c}\text { Fravær/ } \\
\text { Tildelt }\end{array}$ \\
201 Korps & 7,163 & 5,192 & $72 \%$ & 366 & $7 \%$ \\
203 Korps & 6,829 & 4,651 & $68 \%$ & 843 & $18 \%$ \\
205 Korps & 10,018 & 6,921 & $69 \%$ & 1,323 & $19 \%$ \\
207 Korps & 3,638 & 2,302 & $63 \%$ & 292 & $13 \%$ \\
209 Korps & 3,638 & 2,462 & $68 \%$ & 194 & $8 \%$ \\
Total: & 31,286 & 21,528 & $69 \%$ & 3,018 & $14 \%$ \\
\hline
\end{tabular}

Kilde: Combined Security Transition Command Afghanistan (CSTC-A) April 2007. 
tre ugers orlov, hvorefter den gentages. Cyklusen har til formål at vise den enkelte soldat, hvornår han kan forvente at få orlov og i hvor lang tid. De to korps i syd og øst har dog haft svært ved at overholde tidsinddelingen i cyklusen på grund af det krævende operationsmiljø, og af den simple grund at en soldat, der er stationeret i syd, kun vanskeligt kan nå til Nordafghanistan og tilbage i løbet af tre uger.

På materielsiden har man, modsat uddannelsen af de enkelte soldater, været lang tid om at beslutte, hvordan ANA skulle ekviperes med køretøjer, våben og personlig udrustning.

Da USA påbegyndte etableringen af ANA tilbage i 2002, valgte man at satse på materieldonationer fra udlandet. Det betød, at man hurtigt blev bragt i en situation, hvor ANA bestod af blandt andet indiske, pakistanske, russiske og amerikanske køretøjer, af russiske, rumænske og amerikanske våben samt personlig udrustning fra et endnu større antal lande. Den store uensartethed resulterede $\mathrm{i}$, at ANA fik nogle helt uoverskuelige logistiske og uddannelsesmæssige udfordringer, der gjorde opbygningen træg og mindskede den selvstændige bæredygtige udvikling af ANA.

Med disse erfaringer i baghovedet blev det i 2006 besluttet at sætte fart på materielprofessionaliseringen af ANA. Man er således gået i gang med at anskaffe en del nyt materiel til de fem korps, så disse på sigt vil nå op på samme niveau som mange NATO-lande. Konkret er ANA i færd med at implementere amerikanske M16 geværer, amerikanske M113 pansrede mandskabsvogne og amerikanske HUMMWEs (Hummer) alt sammen doneret af USA. Man er også ved at undersøge muligheden for donationer til implementeringen af Leopard 1 kampvogne i ANA.

\section{Træningen af ANA}

Træningen af ANA er anført af USA med støtte fra først og fremmest Storbritannien og Frankrig. Amerikanerne leder den centralt styrede grunduddannelse - som gennemføres i Kabul på Kabul Military Training Center - samt den øverste officersuddannelse. Briterne støtter opbygningen i form af en mellemlederuddannelse, hvilket er et helt nyt element i den afghanske hær, og franskmændene leder den grundlæggende officersuddannelse samt det nye afghanske officersakademi.

Traditionelt har tidligere tiders afghanske hære kun bestået af to niveauer - menige og officerer - men ANA har fået tilføjet et mellemlederniveau efter vestlig inspiration. Uddannelsen af mellemledere er som nævnt anført af Storbritannien og har til formål at skabe en hær, der mere effektivt kan imødegå den sikkerhedstrussel landet på nuværende tidspunkt står overfor.

Mellemlederniveauet reducerer 
den enkelte officers span of control. Uden mellemlederniveauet har en delingsfører ca. 30 mand direkte under sin kommando. Ved at opdele delingen i tre grupper med hver en mellemleder - sergent - som fører, reduceres dette span of control betragteligt. Konkret skaber man herved en mere effektiv kampenhed, der specielt i den komplekse afghanske kontekst er brug for.

Den britiske hær har traditionelt et meget stærkt mellemlederniveau, hvorfor de er blevet ansvarlige for denne del af uddannelsen. ANA og officerskorpset har modtaget introduktionen af mellemlederniveauet med blandede følelser. Mange af officererne vil gerne føre alle soldaterne personligt og har svært ved at uddelegere ansvar til de lavere niveauer. Ofte er det først under operationerne i felten, at officererne ved selvsyn oplever fordelene ved mellemlederniveauet og derefter accepterer det.

Den centrale amerikanske ledelse af træningsindsatsen arbejder i øjeblikket på at omlægge hele uddannelsesstrukturen for ANA med henblik på at frigøre ressourcer til opbygningen af den afghanske politistyrke. Intentionen bag omlægningen er at sende et større antal amerikanske National Guardinstruktører med politiuddannelse til Afghanistan for at opbygge en støtteog uddannelsesstruktur, som den der på nuværende tidspunkt er etableret for ANA.
Samtidig har Washington udtrykt $ø$ nske om, at ISAF overtager uddannelses- og mentoransvaret for ANA ved det centrale træningscenter i Kabul. Derved håber amerikanerne at frigøre de ønskede ressourcer til ANP. I skrivende stund har ingen af de øvrige NATO-lande imidlertid meldt positivt tilbage på den amerikanske forespørgsel.

For at sætte skub i 'afganiseringen' af oprørsbekæmpelsen har amerikanerne ændret de officielle mål for uddannelsen af ANA fra udgangen af 2010 til udgangen af 2008. Officielt er fremrykningen blevet begrundet med, at behovet for soldater er stærkt stigende i de uroplagede egne af landet, og at man derfor har foretaget en afvejning af kvalitet over for kvantitet i forhold til uddannelsen. Det er her blevet vurderet, at den centrale grunduddannelse i Kabul på sigt kan afkortes ved, at den resterende uddannelse gennemføres decentralt ved et af de fem korpshovedkvarterer.

Konsekvensen af denne beslutning bliver, at behovet for instruktører ved de fem korps - og specielt ved 203. og 205. korps - i henholdsvis $\emptyset_{\text {st- og Sydafghanistan vil stige }}$ markant, hvis ANA-soldaterne skal nå at gennemføre den nødvendige uddannelse forud for indsættelse i operationer. Opstilles denne ekstra kapacitet ikke af ISAF, vil man kunne forvente et markant fald i uddannelsesniveauet ved de korps, der på 
nuværende tidspunkt er mest involveret $\mathrm{i}$ kampoperationerne.

\section{Operativt virke og NATO-rådgivere}

På det operative niveau klarer ANA sig generelt godt. Enhederne, der indsættes i kampoperationer, har overordnet betragtet en høj kampmoral og optræder professionelt og engageret. Der er dog stadig lang vej til en egentlig overtagelse af de militære opgaver fra de internationale styrker.

På de lavere niveauer kan delinger og kompagnier som udgangspunkt selv planlægge og gennemføre selvstændige operationer, men bevæger man sig op på bataljons- og brigadeniveau hører selvstændigheden op. På bataljonsniveau kan ANA planlægge operationer, men ikke gennemføre dem uden en kraftig involvering fra de internationale styrker. Specielt ildstøtte, logistik og kommando og kontrol er områder, hvor ANA endnu har lang vej at gå.

For at afhjælpe disse problemer og for at styrke uddannelsen og vejen mod et bæredygtigt og selvstændigt ANA, er de afghanske enheder endvidere blevet tildelt et større antal 'militærrådgivere'. Disse rådgivere - med betegnelsen Operational Mentoring and Liason Teams (OMLTs) - består af soldater, normalt officerer og befalingsmænd, fra forskellige nationer inden for ISAF-styrken.

Rådgiverne indgår $\mathrm{i}$ alle led lige fra deling (ca. 30 mand) til brigade (ca. 3.000 mand). Her gennemfører de vejledning og uddannelsesprogrammer for ANA-enhederne såvel i felten som i lejrene. Under det feltarbejde forfatterne til denne artikel gennemførte i Afghanistan i april 2007, blev der aflagt besøg ved 3. Brigade under 205. Korps i Helmand. Til støtte for brigaden har briterne oprettet et OMLT-hold bestående af ca. 280 officerer og befalingsmænd, der i seks måneder følger de forskellige ANA-enheder i alt fra træning til egentlige kampoperationer.

Under besøget ved 3. Brigade havde den ene af denne artikels forfattere lejlighed til at besøge en ANAenhed, der var stationeret ved Kajaki-dæmningen i det nordlige Helmand. Enheden, der bestod af 36 ANA-soldater og otte engelske OMLTs, havde været stationeret ved dæmningen - i en Forward Operation Base - i ca. fire uger, og havde i den periode været på egentlige kamppatruljer omkring halvdelen af tiden. Under besøget gennemførte ANA sammen med en engelsk enhed patruljer i nærområdet, og de observationer, der her blev gjort, var generelt positive.

ANA-enheden, der bestod af pashtuner, tajiker, hazarer og usbeker, fremstod som en sammentømret enhed, der optrådte professionelt og veldisciplineret under patruljen. Soldaterne virkede ikke skræmte, men havde tværtimod en god kampmoral og professionalisme på det taktiske 
niveau. De engelske OMLTs, der fulgte delingen virkede primært som rådgivere, men var dog i flere tilfælde nødt til at overtage føringen. Navnlig når ANA's materiel viste sig utilstrækkeligt. Problemet var størst på den del af patruljen, der blev gennemført om natten, hvor ANA's mangel på natkikkerter og radiokommunikation svækkede mulighed for uset og lydløs fremrykning.

Indtrykkene fra besøget lader sig naturligvis ikke overføre til ANA som helhed, men mange af observationerne på det mere taktiske plan synes på baggrund af samtaler med højtstående officerer i ISAF-styrken at være gældende for hele styrken. Enhedernes etniske sammensætning, der i vid udstrækning afspejler landets generelle etniske sammensætning, har på de lavere niveauer haft en positiv effekt i form af anerkendelse fra befolkningen og fravær af ANA-interne konflikter.

Den etniske sammensætning har dog skabt problemer på de højere niveauer primært fra brigade og op til ministeriet, hvor prestige og historiske forhold gør, at for eksempel en pashtun har vanskeligt ved at underlægge sig kommando af en hazara. Problemet er dog ikke så omfattende, at det hæmmer udviklingen af ANA betydeligt.

Selve systemet med OMLT og deres virke ved enhederne både i forbindelse med træning og på operationer er helt klart et element, der skaber en stor effekt. Problemet ved systemet er dog, at den belastning, rådgiverne udsættes for i form af krav til konstant at uddanne og efteruddanne ANA-soldaterne, er stort og konstant stigende. Dette vil blive yderligere udtalt, når amerikanerne reducerer uddannelsestiden i Kabul og derved lægger et større pres på de rådgiverhold, der i dag er stationeret sammen med ANA-enhederne i felten.

Man må desuden forvente, at kamphandlingernes kompleksitet i specielt de sydlige og østlige egne vil stige i takt med Talebans overgang til en mere asymmetrisk form for kamp. Dette vil igen stille store krav til konstant at højne niveauet og rådgivningen af ANA-enhederne.

\section{Konklusion}

I løbet af foråret 2007 har USA og de NATO-lande, der er repræsenteret med kampenheder i de sydlige og østlige dele af Afghanistan, forøget presset på de øvrige alliancemedlemmer for at bringe dem til at bidrage med flere trænere og rådgivere i det oprørsplagede land. Set i lyset af at Vesten er involveret i et komplekst 'uafhængighedsoprør', er det en ganske fornuftig allokering af de knappe ressourcer.

Vejen til et stabilt og sikkert Afghanistan går uuomgængeligt over en afghanisering af konflikten, og der er derfor god ræson $i$ at forcere opbygningen af såvel ANA som ANP. Får den afghanske befolkning opfat- 
telsen af, at de nationale sikkerhedsstyrker er på vej til at blive en troværdig sikkerhedsgarant - også efter at de internationale styrker har forladt landet - er meget nået.

På nuværende tidspunkt er udsigterne til at ANA kan overtage samtlige de internationale styrkers funktioner ganske vist lange. Mange års borgerkrig og de fortsatte kampe i de sydlige og østlige dele af landet har i vid udstrækning bidraget til at forsinke opbygningsprocessen, og mange afghanere tvivler på, at Vesten vil efterlade et Afghanistan, der har den tilstrækkelige kapacitet til at håndtere de interne sikkerhedsproblemer.

Denne usikkerhed kan imidlertid reduceres betragteligt, hvis befolkningen får demonstreret, at ANA er i stand til selvstændigt at håndtere sikkerhedsopgaverne i dele af landet. ISAF bør derfor kraftig overveje, om ikke tiden er moden til at overdrage sikkerhedsansvaret for Nord- og - senere - Vestafghanistan til ANA.

Med den amerikanske justering af målet om at have uddannet 70.000 soldater ved udgangen af 2008 - og ikke som oprindelig planlagt 2010 vil behovet for OMLTs stige betydeligt. Dette skal sammenholdes med forkortelsen af den centrale uddannelse af ANA i Kabul og kamphandlingernes voksende kompleksitet, der igen skærper kravene til rådgivnings- og mentorholdene.

Hvis den positive udvikling i ANA skal fortsætte, er det vigtigt at ISAF i stor udstrækning overtager lederskabet og ansvaret for den videre opbygningsindsats. Skal de langsigtede mål for den internationale militære tilstedeværelse i Afghanistan honoreres, er det afgørende at man også i den faktiske implementering af missionen sigter efter disse mål og ikke fortaber sig i de mere kortsigtede taktiske sejre.

ISAF bør derfor opstille en styrket OMLT-struktur, der kan overtage opgaven fra amerikanerne, så disse kan styrke opbygningen af en effektiv politistyrke. De ekstra rådgivere, der skal tilvejebringes, bør rimeligvis komme fra de nationer, der ikke er involveret i kampoperationerne i Syd- og Østafghanistan.

Jens Ringsmose er cand.mag. og forsker ved DIMS (Dansk Institut for Militere Studier).

Peter Dahl Thruelsen er cand.scient.pol. og forskningsmedarbejder ved Institut for Strategi, Forsvarsakademiet 